\title{
Study on the Effect of Thermal Processing on Ready-To-Eat Poultry Egg Keema
} Ashraf G*, Sonkar C, Masih D and Shams R

Department of Food Process Engineering, Sam Higginbottom University of Agriculture, Technology and Sciences, Allahabad, UP, India

\begin{abstract}
Study was conducted to analyze the characteristics of thermally processed ready-to-eat poultry egg keema. Egg keema was prepared as per standardized procedure i.e., utilizing gravy from vegetables i.e., tomato, onion and green peas along with spices and boiled eggs cut into cubes. The product made was filled in pre-sterilized tin cans, sealed hermetically and then thermally processed at different time and temperature combinations viz., $110^{\circ} \mathrm{C}, 115^{\circ} \mathrm{C}$ and $120^{\circ} \mathrm{C}$ for 10 minutes, 15 minutes and 20 minutes respectively in order to interpret the effects of thermal processing. Samples were evaluated initially and after that at regular intervals of 20 days for physico-chemical, microbiological, sensory and statistical analysis during the entire storage period of 60 days. It was found that the ready-to-eat poultry egg keema samples processed at $120^{\circ} \mathrm{C}$ for 10 minutes had adequate fat and ash content while as samples processed at $110^{\circ} \mathrm{C}$ for 10 minutes had adequate protein content. Poultry egg keema samples processed at $120^{\circ} \mathrm{C}$ for 20 minutes had adequate and standard amount of moisture content, desired $\mathrm{pH}$, reduced microbial loads and maximum consumer acceptability in all respects.
\end{abstract}

Keywords: Thermal processing; Ready-to-eat foods; Shelf-life; Canning; Hermetic seal

\section{Introduction}

Poultry eggs play an important role in the human diet and nutrition as an affordable nutrient-rich food commodity that contains highly digestible proteins, lipids, minerals, and vitamins [1]. Over the past 35 years, global egg production has grown to $203.2 \%$, due to rapid increasing demand for proteins in the developing world [2]. Today, eggs remain a staple food within human diet consumed by people throughout the world. They are recognized by consumers as a versatile and wholesome as they have natural balance of essential nutrients. The proximate composition of egg as given by Watkins [3] Whole egg, egg white, egg yolk contains solid content of $24.5 \%, 12.1 \%$, $51.8 \%$ respectively; protein content of $12 \%, 10.2 \%, 16.1 \%$ respectively; carbohydrate content of $1 \%, 1 \%, 1 \%$ respectively; ash content of $1 \%$, $0.68 \%, 1.69 \%$ respectively and lipid content of whole egg and egg yolk is $10.9 \%$ and $34.1 \%$ respectively. Eggs contain approximately $75 \%$ water, $12 \%$ each lipids and proteins, $\sim 1 \%$ carbohydrates and minerals Burley and Vadehra [4] and Li-Chan et al. [5]. Avian eggs are an excellent source of nutrients, particularly high-quality proteins, lipids, minerals, and vitamins [6-8]. There is a growing consumer interest in related eating patterns such as the avoidance or reduced consumption of red meat. An estimated 7 million people currently either avoid red meat or are vegetarians, compared to 2 million in 1984 [9] and the current state of art to produce thermally processed ready-to-eat egg products has increased the commercial value and offered a level of quality, safety and convenience to consumers. Egg products will continue to be an important part of our daily diet as the primary animal protein in many parts of the world, thus new technologies and methods of egg processing will see applications to improve nutrition, safety, shelf-life and taste of egg products, or to create new egg products as functional foods, nutraceuticals and other non-food uses.

Over the centuries world has witnessed change in the pattern of consumption, from raw to cooked to ready-to-eat foods; emergence of it in the global food industry and now to the Indian markets. Ready-toeat foods are foods that are offered for sale without additional cooking or preparation, packaged on the premises where they are being sold and are ready for consumption. Canned foods, convenience foods, fast foods, frozen foods, instant products, dried foods, preserved foods, etc. all come under the category of ready-to-eat foods [10]. The increasing demand by consumer for high quality convenient ready-to-eat foods has led to an increase in the commercial production of these products [11] for example Indian curries, desserts, frozen heat and eat products like chicken and mutton curry, canned beef meat etc. which are generally retorted and are shelf stable [12]. Unlike pasteurized products where the survival of heat resistant microorganisms is accepted, the main aim of sterilization of egg products is the destruction of all microorganisms including their spores. Thermal treatment of ready-to-eat egg products must be intense enough to inactivate/kill the most heat resistant bacterial spores of Bacillus and Clostridium. Temperatures above $100^{\circ} \mathrm{C}$, usually ranging from $110^{\circ} \mathrm{C}$ to $121^{\circ} \mathrm{C}$ are applied to achieve the goal [13].

\section{Materials and Methods}

\section{Preparation of ready-to-eat poultry egg keema}

Poultry eggs properly washed were boiled for about 20 minutes, cooled, shelled and cut into cubes keeping the yolk intact. Gravy was made as per the standardized procedure by frying vegetables in oil along with the ground dried spices until golden brown. Then water, mint, coriander leaves and green peas were added and cooked until all water was evaporated and thick curry left behind. Finally chopped eggs were added to the curry.

\section{Thermal processing of ready-to-eat poultry egg keema}

The poultry egg keema was filled into pre-sterilized cans maintaining a proper head space $(1.10 \mathrm{~cm})$. After filling, exhausting was done in hot water bath at $82^{\circ} \mathrm{C}$ for 10 minutes. Cans were then sealed with double seaming machine after which they were thermally processing in an autoclave at different time and temperature combinations. After

*Corresponding author: Ashraf G, Department of Food Process Engineering Sam Higginbottom University of Agriculture, Technology and Sciences, Allahabad, UP, India, Tel: 8562940248; E-mail: gousiamir123@gmail.com

Received June 22, 2017; Accepted July 14, 2017; Published July 21, 2017

Citation: Ashraf G, Sonkar C, Masih D, Shams R (2017) Study on the Effect of Thermal Processing on Ready-To-Eat Poultry Egg Keema. J Food Process Technol 8: 684. doi: 10.4172/2157-7110.1000684

Copyright: @ 2017 Ashraf G, et al. This is an open-access article distributed unde the terms of the Creative Commons Attribution License, which permits unrestricted use, distribution, and reproduction in any medium, provided the original author and source are credited. 
thermal processing cans were cooled in a vessel containing tap water to reduce the temperature, dried and finally stored in cool and dry place at ambient temperatures $\left(25^{\circ} \mathrm{C}\right.$ to $\left.30^{\circ} \mathrm{C}\right)$.

\section{Proximate and chemical analysis}

Moisture, protein, fat, ash, $\mathrm{pH}$ of the thermally processed samples was determined initially and at the regular intervals of 20 days for 60 days storage period as per AOAC.

\section{Microbiological analysis}

Thermally processed ready-to-eat poultry egg keema was analyzed for commercial sterility at the regular intervals of 20 days for 60 days of entire storage period. Standard plate count was determined using nutrient agar for incubation at $37^{\circ} \mathrm{C}$ for 24 hours while as yeast and mold count was determined using Potato Dextrose Agar (PDA) for incubation at $37^{\circ} \mathrm{C}$ for 48 hours to 72 hours.

\section{Sensory analysis}

Sensory evaluation of thermally processed ready-to-eat poultry egg keema was done using 9-point Hedonic scale which is the basis to differentiate between pleasurable and un-pleasurable experiences to determine the effect of different thermal treatments on the organoleptic properties like color, taste, flavor, aroma and overall acceptability.

\section{Statistical analysis}

Statistical analysis was conducted as per the data obtained from three levels of temperatures for three levels of time periods i.e., from 9 treatments and 3 replications during trial and was analyzed statistically by Analysis of Variance technique, 3-way classification considering the effect of time, temperature and days on the product. The significant effect of treatments i.e., time, temperature and days was judged with the help of ' $F$ ' (variance ratio). Calculated values of $F$ were compared with the table value of $\mathrm{F}$ at $5 \%$ level of significance (0.05) (Table 1).

\section{Results and Discussion}

\section{Effect of thermal processing on ready-to-eat poultry egg} keema

The product standardization of poultry egg keema was done in cans filled to constant weight i.e., $500 \mathrm{~g}$ maintaining $1.10 \mathrm{~cm}$ headspace and then adequacy of thermal processing was maintained at different time and temperature combinations i.e., $110^{\circ} \mathrm{C}, 115^{\circ} \mathrm{C}$ and $120^{\circ} \mathrm{C}$ for 10 minutes, 15 minutes and 20 minutes. The cans were stored at ambient temperature i.e., $25^{\circ} \mathrm{C}$ to $30^{\circ} \mathrm{C}$. The sensory evaluation of the ready-to-eat poultry egg keema was done on the basis of organoleptic characteristics to indicate its definite maturation and improvement during storage and it was observed that the samples thermally processed

\begin{tabular}{|c|c|}
\hline Ingredients & Weight \\
\hline Poultry Eggs (Nos.) & 100 \\
\hline Onion $(\mathrm{kg})$ & 2.5 \\
\hline Tomato $(\mathrm{kg})$ & 1.5 \\
\hline Green peas (g) & 500 \\
\hline Soya-bean oil (ml) & 300 \\
\hline Ginger garlic paste (g) & 120 \\
\hline Chilli powder (g) & 70 \\
\hline Turmeric powder (g) & 10 \\
\hline Salt (g) & 180 \\
\hline Water (L) & 2.5 \\
\hline
\end{tabular}

Table 1: The ingredients used in the preparation of poultry egg keema. at $120^{\circ} \mathrm{C}$ for 20 minutes were acceptable in all respects. Similar results were interpreted during the chemical, microbial and sensory analysis of canned meat based mutton and beef curry Madhwaraj [14], Rajkumar et al. [15] evaluated the appearance, color, flavor, juiciness, texture and overall acceptability of Chettinad goat meat curry showing scores of 8.0 to 8.4 on a 9-point hedonic scale after thermal treatment.

\section{Composition of ready-to-eat poultry egg keema in cans} $1 \%$ ash

Poultry eggs: $65 \%$ moisture, $12 \%$ to $14 \%$ protein, $10 \%$ to $12 \%$ fat,

Boiled egg cubes considered for each can: $250 \mathrm{~g}$

Gravy made with vegetables and spices for each can: $250 \mathrm{~g}$

Weight of empty can: $100 \mathrm{~g}$

Weight of each packed can: $600 \mathrm{~g}$ (i.e., $500 \mathrm{~g}$ egg keema and $100 \mathrm{~g}$ weight of can)

\section{Chemical Characteristics of Ready-To-Eat Poultry Egg Keema}

\section{Effect of thermal processing on moisture percentage of ready- to-eat poultry egg keema}

Mean value of moisture percentage at 0 days of storage at $120^{\circ} \mathrm{C}$ i.e., 69.50 was significantly superior to the mean value at $115^{\circ} \mathrm{C}$ i.e., 69.49 which again was found significantly superior to $110^{\circ} \mathrm{C}$ i.e., 69.45. For time treatments, it was observed that the mean value at 20 minutes i.e., 69.34 was significantly superior to the mean value at time 15 minutes i.e., 69.54 which again was significantly superior to 10 minutes i.e., 69.57. Also during the interaction analysis (both time and temperature) mean moisture percentage of samples processed at $120^{\circ} \mathrm{C}$ for 20 minutes i.e., 69.48 was significantly superior to the interaction at $115^{\circ} \mathrm{C}$ for 20 minutes i.e., 69.31 which was again superior to $110^{\circ} \mathrm{C}$ for 20 minutes i.e., 69.24. Similar results were depicted after the analysis of 20 days, 40 days and 60 days of storage. It was observed from the findings that the moisture percentage of poultry egg keema slightly decreased during canning, cooking as the temperature increased. High moisture content results in microbial growth during canning of meat by using different gravy's. Moisture content decreases as the temperature increases [16]. Statistical analysis showed that the calculated value of $\mathrm{F}$ due to treatments (time, temperature and days) is greater than the tabulated value at $5 \%$ probability level concluding the significant effect of treatments on moisture content of samples (Figure 1).

Effect of thermal processing on protein percentage of readyto-eat poultry egg keema

Mean value of protein percentage at 0 days storage at $110^{\circ} \mathrm{C}$ i.e.,

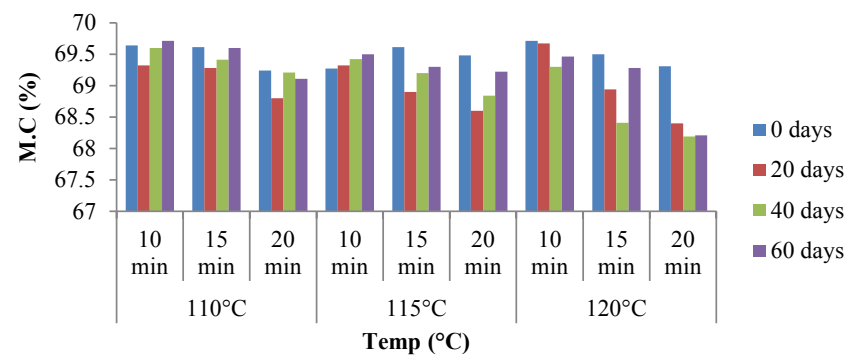

Figure 1: Effect of thermal processing on moisture percentage of ready-to-ea poultry egg keema. 
15.35 was significantly superior to the mean value at $115^{\circ} \mathrm{C}$ i.e., 15.29 which again was significantly superior to $120^{\circ} \mathrm{C}$ i.e., 15.17 . For time treatments, it was observed that the mean value at time 10 minutes i.e., 15.38 was significantly superior to the mean value at 15 minutes i.e., 15.28 which again was significantly superior to 20 minutes i.e., 15.14 . Also during the interaction analysis (both time and temperature) mean protein percentage of samples processed at $110^{\circ} \mathrm{C}$ for 10 minutes i.e., 15.43 was significantly superior to the interaction at $115^{\circ} \mathrm{C}$ for 10 minutes i.e., 15.42 which was again superior to $120^{\circ} \mathrm{C}$ for 10 minutes i.e., 15.31. Similar results were depicted after the analysis of 20 days, 40 days and 60 days of storage. It was observed from the findings that proteins present in poultry egg keema denatured at higher temperatures thus affecting their physical properties and decreasing the biological value. Morgan and Kern [17] found that during the canning of meat, the biological activity of the proteins decreased as the severity of heat treatment increased. Processes like canning and roasting may adversely affect the meat protein properties by bringing changes in their linkages and making them unsusceptible to enzymatic digestion [18]. Statistical analysis showed that the calculated value of $\mathrm{F}$ due to treatments (time, temperature and days) is greater than the tabulated value at $5 \%$ probability level concluding the significant effect of treatments on protein content of samples (Figure 2).

\section{Effect of thermal processing on fat percentage of ready-to-eat poultry egg keema}

Mean value of the fat percentage at 0 days storage at temperature $120^{\circ} \mathrm{C}$ i.e., 18.66 was significantly superior to the mean value at temperature $110^{\circ} \mathrm{C}$ i.e., 18.36 which again was found significantly superior to $115^{\circ} \mathrm{C}$ i.e., 18.24 . For time treatments, it was observed that the mean value at time 20 minutes i.e., 18.50 was significantly superior to the mean value at time 15 minutes i.e., 18.43 which again was significantly superior to $10 \mathrm{~min}$ i.e., 15.33. Also during the interaction analysis (both time and temperature) mean fat percentage of samples processed at $120^{\circ} \mathrm{C}$ for 10 minutes i.e., 18.82 was significantly superior to the interaction at $110^{\circ} \mathrm{C}$ for 10 minutes i.e., 18.12 which was again superior to $115^{\circ} \mathrm{C}$ for 10 minutes i.e., 18.07. Similar results were depicted after the analysis of 20 days, 40 days and 60 days of storage.

The higher temperature and time combinations decreased the fat percentage of the product during storage due to the possibility of breakage of long chain fatty acid chains into individual fatty acid moiety. Increased temperatures influence the physical properties of meat fat [16]. Similar results were obtained during the determination of fat in canned meats [14]. Statistical analysis showed that the calculated value of $\mathrm{F}$ due to treatments time and temperature is less than the tabulated value at $5 \%$ probability level but reverse is observed for the effect of days, concluding the significant effect of days and insignificant of time and temperature on fat content of samples (Figure 3 ).

\section{Effect of thermal processing on $\mathrm{PH}$ of ready-to-eat poultry egg keema}

Mean value of the $\mathrm{pH}$ at 0 days storage at temperature $120^{\circ} \mathrm{C}$ i.e., 5.61 and $115^{\circ} \mathrm{C}$ i.e., 5.60 was found significantly superior to $110^{\circ} \mathrm{C}$ i.e., 5.57. For the time treatments, it was observed that mean value at time 20 minutes i.e., 5.96 was significantly superior to the mean value at time 15 minutes i.e., 5.59 which again was superior to the mean value at 10 minutes i.e., 5.57. Also during the interaction analysis (both time and temperature) mean $\mathrm{pH}$ of samples processed at $120^{\circ} \mathrm{C}$ for 20 minutes i.e., 5.63 was significantly superior to the interaction at $115^{\circ} \mathrm{C}$ for 20 minutes i.e., 5.63 which was again superior to $110^{\circ} \mathrm{C}$ for 20 minutes i.e., 5.59. Similar results were depicted after the analysis of 20 days, 40 days and 60 days of storage.

The $\mathrm{pH}$ of egg never reaches such high acid values but the higher temperatures of about $110^{\circ} \mathrm{C}$ to $115^{\circ} \mathrm{C}$ favors the reaction. The results are in accordance with Morgan and Kern [17] who stated that during meat roasting and canning, if the $\mathrm{pH}$ of the product lies between 5.45.8 , it will be edible. The results are in conformation with the study on the effect of thermal processing on shelf stable canned salted beef with tomato gravy [19]. Statistical analysis showed that the calculated value of $\mathrm{F}$ due to treatments (time, temperature and days) is greater than the tabulated value at $5 \%$ probability level, concluding the significant effect of treatments on $\mathrm{pH}$ of samples (Figure 4).

\section{Effect of thermal processing on ash percentage of ready-to-eat poultry egg keema}

Mean value of the ash percentage at 0 days storage at temperature

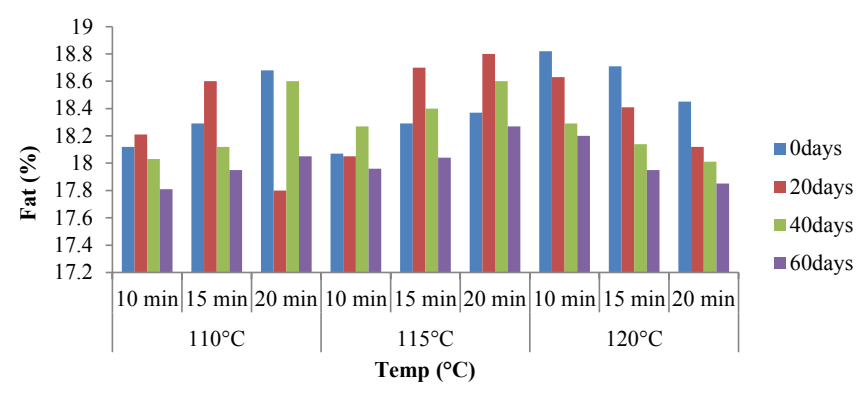

Figure 3: Effect of thermal processing on fat percentage of ready-to-eat poultry egg keema.

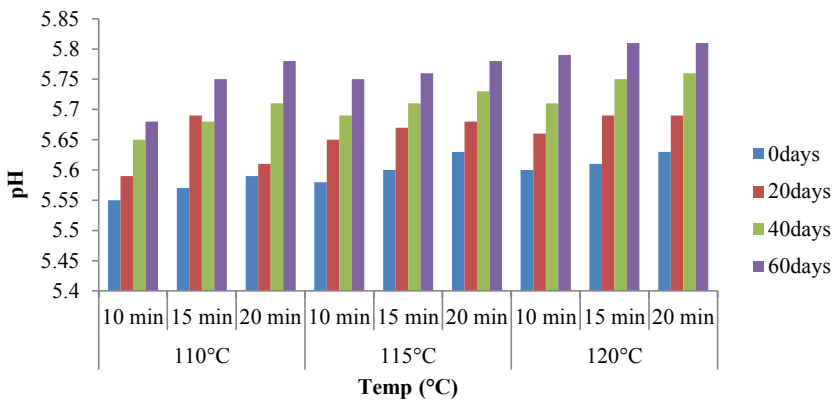

Figure 4: Effect of thermal processing on $\mathrm{pH}$ of ready-to-eat poultry egg keema.

poultry egg keema. 
$120^{\circ} \mathrm{C}, 115^{\circ} \mathrm{C}$ and $110^{\circ} \mathrm{C}$ were comparable i.e., 1.83 . For the time treatments, it was observed that mean value at time 10 minutes i.e., 2 was significantly superior to the mean value at time 15 minutes and 20 minutes i.e., 1.83. Also during the interaction analysis (both time and temperature) mean ash percentage of samples processed at $120^{\circ} \mathrm{C}$ for 10 minutes, $115^{\circ} \mathrm{C}$ for 10 minutes and $110^{\circ} \mathrm{C}$ for 10 minutes is 2 . Similar results were depicted after the analysis of 20 days, 40 days and 60 days of storage.

The processing and cooking methods had little or no effect on the mineral elements of food products as suggested by Ackurt [20]; Gall et al. [21]; Steiner-Asiedu et al. [22]. Cooking is responsible for mineral losses due to their sensitivity to heat, oxygen, $\mathrm{pH}$ of solvent or combination of these as described by Harris [23]. Potassium is probably the most sensitive mineral lost during cooking [24]. Statistical analysis showed that the calculated value of $\mathrm{F}$ due to treatments (time and days) is greater than the tabulated value at $5 \%$ probability level but the reverse is observed due to effect of temperature concluding the significant effect of time and days and insignificant effect of temperature on ash content of samples (Figure 5).

\section{Effect of thermal processing on microbiological characteristics of ready-to-eat poultry egg keema}

Mean value of standard plate count (SPC) at temperature $120^{\circ} \mathrm{C}$ i.e., 30.33 was significantly superior to the mean value at temperature $115^{\circ} \mathrm{C}$ i.e., 44.66 which was again significantly superior to $110^{\circ} \mathrm{C}$ i.e., 54 . For time treatments, it was observed that the mean value at 20 minutes i.e., 26.66 was significantly superior to 115 minutes i.e., 43 which was again significantly superior to 10 minutes i.e., 59.33. Also during the interaction analysis (both time and temperature) mean SPC of samples processed at $120^{\circ} \mathrm{C}$ for 20 minutes i.e., 16 was significantly superior to interaction at $115^{\circ} \mathrm{C}$ for 20 minutes i.e., 30 which again was significantly superior to $110^{\circ} \mathrm{C}$ for 20 minutes i.e., 34. Similar results were depicted after the analysis of 20 days, 40 days and 60 days of storage.

The results are in accordance with Kumar et al. [25], Agathian et al. [26] who studied retort processed ready-to-eat foods and found commercial sterility after retort processing and the entire period of the storage under different temperature. Rajkumar et al. [15] determined total viable, anaerobic, coliform, staphylococcal, streptococcal, clostridial and yeast and mold counts of Chettinad goat meat curry retorted to an $\mathrm{F}_{0}$ value of 12.1 minutes and showed that the product was commercially sterile. Statistical analysis showed that the calculated value of $F$ due to treatments (time, temperature and days) is greater than the tabulated value at $5 \%$ probability level, concluding the significant effect of treatments on the microbial count of samples (Figure 6).

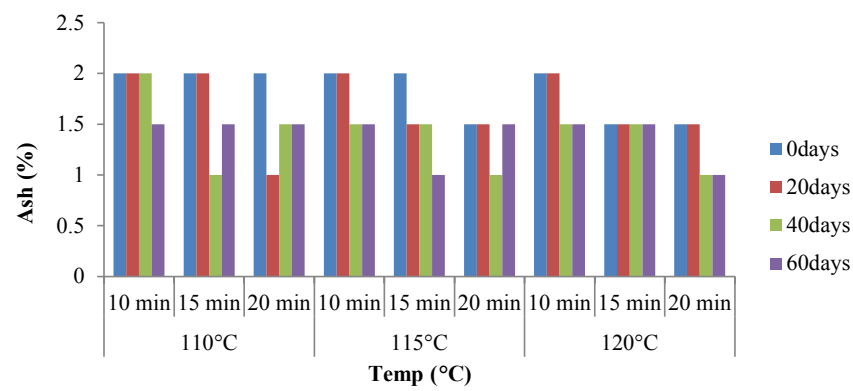

Figure 5: Effect of thermal processing on ash percentage of ready-to-eat poultry egg keema.

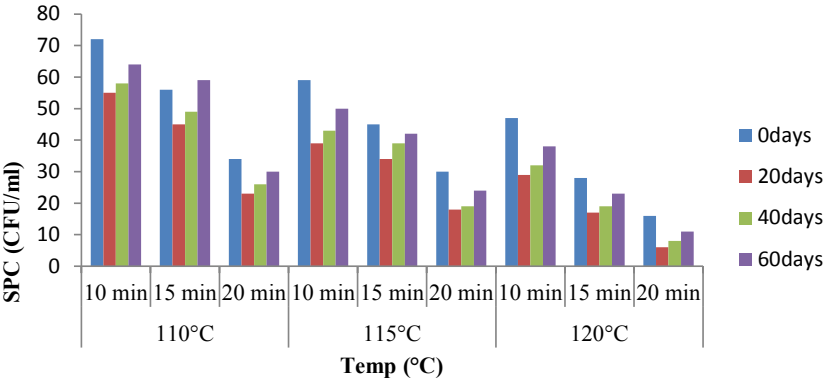

Figure 6: Effect of thermal processing on microbiological characteristics of ready-to-eat poultry egg keema.

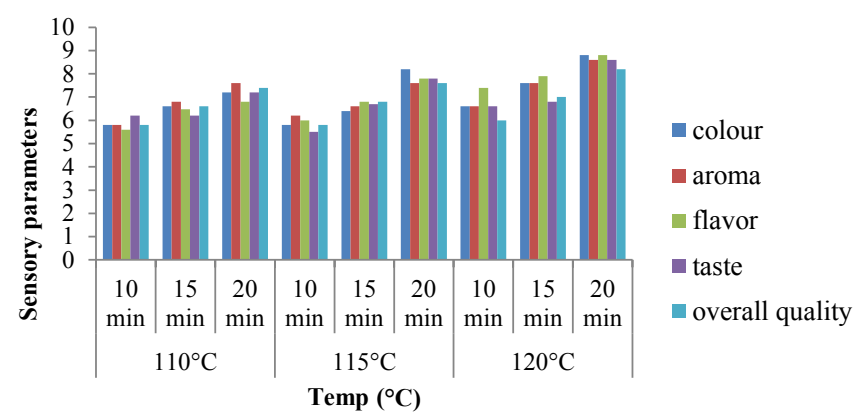

Figure 7: Effect of thermal processing on overall acceptability of ready-to-eat poultry egg keema.

\section{Effect of thermal processing on sensory characteristics of ready-to-eat poultry egg keema}

Mean value of sensory scores showed that the ready-to-eat poultry egg keema thermally processed at $120^{\circ} \mathrm{C}$ for 20 minutes had significant mean sensory score as compared to that of control which clearly depicts its shelf stability and maximum acceptability [27-29].

\section{Effect of thermal processing on overall acceptability of ready- to-eat poultry egg keema}

Mean value of sensory scores for overall acceptability at temperature $120^{\circ} \mathrm{C}$ i.e., 7.06 was significantly superior to mean value at temperature $115^{\circ} \mathrm{C}$ i.e., 6.73 which was again significantly superior to $110^{\circ} \mathrm{C}$ i.e., 6.60 . For time treatments, it was observed that the mean value at 20 minutes i.e., 7.73 was significantly superior to 15 minutes i.e., 6.80 which was again significantly superior to 10 minutes i.e., 5.86. Also during the interaction analysis (both time and temperature) of mean sensory scores of overall acceptability of samples processed at $120^{\circ} \mathrm{C}$ for 20 minutes i.e., 8.2 was significantly superior to the interaction at $115^{\circ} \mathrm{C}$ for 20 min i.e., 7.6 which again was significantly superior to $110^{\circ} \mathrm{C}$ for 20 minutes i.e., 7.4. Similar results were depicted after the analysis of 20 days, 40 days and 60 days of storage and also during analysis of color, taste, aroma and flavor. The results are in accordance with Gopal et al. [28] who evaluated Kerala style fish curry and showed an overall acceptance of 8.0 on a 9-point scale rating after heat treatment, which then decreased to 7.5 after 12 months of storage (Figure 7).

\section{Conclusion}

The present study revealed that due to application of thermal 
Citation: Ashraf G, Sonkar C, Masih D, Shams R (2017) Study on the Effect of Thermal Processing on Ready-To-Eat Poultry Egg Keema. J Food Process Technol 8: 684. doi: 10.4172/2157-7110.1000684

processing at different time and temperature combinations, the microbial stability, sensory attributes as well as the nutritive characteristics of the ready-to-eat poultry egg keema were retained. Poultry egg keema samples thermally processed at $120^{\circ} \mathrm{C}$ for 20 minutes had significantly superior acceptability, adequate moisture content and $\mathrm{pH}$. Samples processed at $110^{\circ} \mathrm{C}$ for 10 minutes had adequate protein content as compared to samples processed at other temperature and time combinations. Samples processed at $120^{\circ} \mathrm{C}$ for 10 minutes had adequate fat and ash content as compared to samples processed at other temperature and time combinations. Similarly, the maximum decline in the microbial load was depicted after the poultry egg keema was thermally processed at $120^{\circ} \mathrm{C}$ for 20 minutes. Results from the temperature and time measurements along with microbiological tests showed that the product was commercially sterile and acceptable throughout the storage period of 60 days.

\section{References}

1. Fisinin VI, Papazyan TT, Surai PF (2008) Producing specialist poultry products to meet human nutrition requirements: Selenium enriched eggs. World's Poultry Sci J 64: 85-98.

2. Windhorst HW (2007) Changes in the structure of global egg production World's Poultry Sci J 23: 24-25.

3. Watkins BA (1995) The nutritive value of the egg. The Haworth Press Inc, New York, USA.

4. Burley RW, Vadehra DV (1989) The avian egg: Chemistry and biology. Wiley publications, New York, USA.

5. Li-Chan E, Powrie WD, Nakai S (1995) The chemistry of eggs and egg products. Food Products Press, New York, USA

6. Herron KL, Fernandez ML (2004) Are the current dietary guidelines regarding egg consumption appropriate? J Nutri 134: 187-190.

7. Kovacs-Nolan J, Phillips M, Mine $Y(2005)$ Advances in the value of eggs and egg components for human health. J Agri Food Chem 53: 8421-8431.

8. Li-Chan E, Kim HO (2008) Structure and chemical composition of eggs. Egg Biosci Biotechnol pp: 1-65.

9. Gregory S (2001) Changing attitudes to meat consumption. Real eat survey.

10. Selvarajn PRM (2012) Consumer attitudes towards ready-to-eat packed food items. The Seventh International Research Conference on Management and Finance pp: 322-332.

11. Kumar R, Johnsy G, Rajamanickam R, Lakshmana JH, Kathiravan T (2013) Effect of gamma irradiation and retort processing on microbial, chemical and sensory quality of ready-to-eat chicken pulav. Int Food Res J 20: 1579-1584.

12. Mann JE, Brashears MM (2004) Contribution of humidity to the lethality of surface-attached heat-resistant salmonella during the thermal processing of cooked ready-to-eat roast beef. J Food Protect 70: 762-765.
13. Han JM, Ledward DA (2004) High pressure/thermal treatment effects on the beef muscle. Meat Science 68: 347-355

14. Madhwaraj MS, Kadkol SB, Nair PR, Dhanraj S, Govindarajan VS (1979) Effect of thermal processing on shelf stable canned salted beef with tomato gravy. Central Food Technological Research Institute, Mysore, India.

15. Rajkumar D, Dushyanthan K, Das AK (2010) Retort pouch processing of Chettinad style goat meat curry a heritage meat product. J Food Sci Technol 47: $372-379$

16. Reiser R, Shorland FB (1990) Meat fats and fatty acids. J Food Sci Technol 5: 21-62.

17. Morgan AF, Andg EK (1934) The effect of heat upon the biological value of meat protein. J Nutrition 7: 367.

18. Howker JJ, Shults GW, Wierbicki E (1976) Effect of combined irradiation and thermal processing on canned beef. Army Natick Research and Development Command Mass Food Engineering Lab. Agri Res Rev 30: 44-48.

19. Singh A, Genitha TR, Singh R, Shakya BR (2012) Effect of thermal processing on shelf stable canned salted beef with tomato gravy. IOSR J Environmental Sci Toxicol Food Technol (IOSR-JESTFT) 1: 11-18.

20. Ackurt $F$ (1991) Nutrient retention during preparation and cooking of meat and fish by traditional methods. Gida Sanayii 20: 58-66.

21. Gall KL, Otwell WS, Koburger JA, Appledorf H (1983) Effects of four cooking methods on proximate, mineral and fatty acid composition of fish fillets. J Food Sci 48:1068-1074.

22. Steiner AM, Julshamn K, Lie $\varnothing$ (1991) Effect of local processing methods (cooking, frying and smoking) on three fish species from Ghana: Part I Proximate composition, fatty acids, minerals, trace elements and vitamins. Food Chem 40: 309-321.

23. Harris RS (1988) General discussion on stability of nutrients. In: nutritiona evaluation of food processing. Van Nostrand Reinstein Co, New York, USA.

24. Adams CE, Erdman JW (1988) Effects of home food preparation practices on nutritional content of foods. Van Nostrand Reinstein Co, New York, USA.

25. Kumar R, Nataraju S, Jayaprahash C, Sabhapathy SN, Bawa AS (2007) Development and evaluation of retort pouch processed ready-to-eat coconut kheer. India Coconut J 37: 2-6.

26. Agathian G, Nataraj S, Sashikanth S, Sabapathy SN, Bawa AS (2009) Development of shelf stable retort pouch processed ready-to-eat dal makhni. Indian Food Packer 63: 55-62.

27. AOAC (2000) Official methods of analysis. Association of Official Analytical Chemists International. Maryland, USA.

8. Gopal TKS, Vijayan PK, Balachandran KK, Madhavan P, lyer TSG (2001) Traditional Kerala style fish curry in indigenous retort pouch. Food Control 12 523-527.

29. Singh A, Genitha TR, Singh R, Shakya BR (2012) Effect of thermal processing on shelf stable canned salted beef with tomato gravy. IOSR J Environmental Sci Toxicol Food Technol (IOSR-JESTFT) 1: 11-18 